\title{
Human Rights in the zones of non-being: Lessons on [not] speaking about and on behalf of "others" from J.M. Coetzee's Foe
}

\author{
JDD, Vol 3 No 12021 \\ DOI: https://doi.org/10.35293/jdd.v3i1.20
}

\section{By Ndumiso Ncube}

University of Pretoria

"It is not speech that makes man man but the speech of others."

J.M. Coetzee (1977: 137)

\section{Abstract}

One of the modern dictates of freedom is a human's right to free speech as enshrined in the United Nations' (2015) Universal Declaration of Humans Rights (UDHR) of 1948. The very concept of "universal" rights foregrounds the question on what and who is human. Following this universal doctrine, all freedoms, including the freedom to free speech translates ultimately to "beings" that are critically self-conscious, or at least beings who are regarded as human-beings, who are allowed to exist, to live, and to be free. Indeed, to examine what has happened to those who exist in Fanon's (2008) zones of non-being who are denied their right to free speech even after the "universal" pronouncements of 1948 is equally important. In fact, all along and even today (and because of coloniality) the Third World citizens may still be denied their right to free speech, their right to be free from economic bondage or otherwise - which are, after all, their natural rights to be human. To be "free", to be "human" or to "live" denotes that one has the ability to speak as the universal declaration accords. The voice (an ability to be heard) or its lack creates beings that are not regarded as human. Indeed, the effects of talking or not talking of the anthropos, or on behalf of them is explored, somewhat as the unreliability and the corruptibility of the authority of language and authorship. This is to say, the meaning and intentions (of the voice) that belongs to those in the zones of non-being are most often misunderstood, mistranslated and sometimes misread and unheard - stripping them of one of their essential human rights to be heard. This way, I seek to investigate the dilemma of the right to free speech in 
J.M. Coetzee's novel Foe (1986) as well as challenge the UDHR declaration that all humans are born equal with a right to freedom of speech. I argue that the possession of language in the world where there are two zones, as illustrated in John Maxwell Coetzee's Foe (1986) does not guarantee one to be heard or liberated.

Keywords: Human Rights, decoloniality, zones of non-being, humanitas, anthropos, J. M. Coetzee

\section{Introduction}

There have been numerous debates on J.M. Coetzee's literary relevance especially in the contemporary South Africa with some critics like Boyd (1983) and Parry (1991) among others, saying that his literary vocation is silent on the injustices happening in South Africa. Some critics like Attridge (2004) argue that readers should not read Coetzee's fiction as allegorical texts but novels that require literary reading. However, Poyner (2006) cogitates that any interpretation is an allegorical act. Interestingly, following the publication of Dovey's (1988) The Novels of J.M. Coetzee: Lacanian Allegories, Chapman (1998) has argued on the correct reading of Coetzee's fiction. Chapman (1998) takes issue with Dovey's (1988) total reliance on Lacanian psychoanalysis in her reading of Coetzee's fiction in her monograph. Rather, Chapman (1998: 327) advocates for Coetzee's fiction to be read as "the mimetic challenge of social intervention and commitment." Thus, Dovey's (1988) reading of Coetzee using structuralist/poststructuralist theory is what Chapman (1998:328) attacks as "Eurocentric bias." In turn Dovey (1998: 483) finds it appalling that "Chapman would like to do away with poststructuralist theory altogether." However, what Chapman (1998: 328) observes is that Coetzee's fiction is very much read by analysing its language, "and too little with political injustice." In other words, Chapman accuses academics of being too preoccupied by language issues in Coetzee's fiction than origins of history in these texts. Chapman (1998: 329) notices that because of this language preoccupation, critics have failed to notice "silences regarding socioliterary debate in South Africa." While Chapman's view provides a launchpad for my argument of voiceless victims, I seek to challenge his view that Coetzee's novels are removed from the cutting-edge of the most crucial debates of the day in this country. My reading of the Coetzee's Foe questions the silencing global power structures - an aspect central in the ongoing decolonial debates.

The critique of Coetzee's silent or voiceless characters is not new as postcolonial critics like Mullins (2009), Smet (2009), Schallenberg (2011) and Foxcroft (2013) among others, 
have appeared to tackle such representations. In fact, postcolonial critics view the silences of Coetzee (1986) characters as a weapon against imperial oppressive forces (mostly by focusing on inverted identities as theorised by Homi Bhabha and Edward Said). However, Schallenberg (2011) has put forward an interesting argument that:

"The one that names is able to understand the world and control it; he or she is in a subjective position. Thus, in a postcolonial situation, a way for the colonized to tack back control over their world is to name it, make their voice heard, where at first the voice of the colonizer was made loudest."

The question still remains: how can the former colonized be heard? Do they have the voice? Are they naming themselves? Speaking of dissenting voices during the discussion and adoption of the UDHR, in her address Eleanor Roosevelt (1948:1) mentions that while the document is not perfect and cannot satisfy every delegate represented, "the whole delegation of the United States believes that this is a good document." Perhaps, some of the uncomfortable questions may be asked: Who were the unsatisfied delegates and where did they come from? Why would the document pass because the rest of Unites States delegates agree? In fact, why would Mrs. Roosevelt single out the United States delegates?

In asking these questions I seek to advance an argument that human rights in the zones of non-being are not equal to the human rights in the zones of being. The zone of non-being is Franz Fanon's (2004) description of people whom he describes as the wretched of the earth. The wretched of the earth are those who still suffer from what Mignolo (2000) calls the colonial wound - a wound inflicted by "colonial difference" (Mignolo: 2011). What divides those in the zone of being from those in the zone of non-being (those who inhabit the house of colonial wounds) is Santo's (2007) abyssal line or Maldonado-Torres's(2007) onto-Manichean line which is a colonist creation to hierarchise humanity thereby pushing the colonised or conquered people out of the human family. Gordon (2007: 10) says that when humans occupy a space below humanity, they live in hellish conditions - an empty space devoid of words. Evidently, while the zone of being is above this line, the zone of nonbeing is not only below but its inhabitants are subjected to colonial gaze. The zone of nonbeing is a zone of non-human space, a zone of the dehumanised that are viewed as excesses. Mbembe (2017: 11) says that "to be an excess is to be fundamentally unrepresentable [... ] and powerfully possessed by emptiness." Today, ironically, the basic principle of the Universal Declaration of Human Rights (UDHR) is to recognise all forms of humanity as equal. However, it has been demonstrated through the politics of the world (or through the 
creation of zones) that it is highly improbable for those in the zone of being and those in the zone of non-being to enjoy equal rights and equal freedoms. That is to say, the notion created by the "universality" of human rights is another form of coloniality of knowledge (the over-reliance on and the rationalising of the Western forms of knowledge and knowledge production) that assume that singular human rights are pluriversal. Indeed, what has resulted is a situation where those who dwell in the zones of being enjoy more rights than those in the zones of non-being. The zones of being do not need to be geographical locals, they are today epistemic zones as demonstrated in Foe, where, after the shipwreck of Cruso, of Susan Barton, and presumably of Friday which meant them destitute, equal and level on the island, Cruso and Susan maintain their superiority through their ability to speak. Indeed, the symbolic island, natural as it is, had to be modernised upon the arrival of Cruso, on his terms.

The UDHR, as a Euro-American centered document, as Maldonado-Torres (2017) and Mignolo (2009) among others have argued (and notwithstanding the fifty-two member states which signed the document in 1948), is a document born to redress the crises leading up to World War II (1933-1945), a war which many countries were dragged into. In a race to colonise and grab as much of the world's land and labour force as possible, the imperial nations (which included Britain, France, Germany and Italy) dragged most of the nations into an imperial war, recruiting soldiers from colonised countries to fight on the side of their imperial masters. I should mention in passing that seventeen million people, including the six million Jews died during World War II, which prompted the same architects of war to sit everyone around the table, under the guidance of Eleanor Roosevelt to find lasting future solutions and police the activities of the Nazi and Fascist countries. The United Nations' (2015) UDHR guiding principle is that "All human beings are born free and equal in dignity and rights. They are endowed with reason and conscience and should act towards one another in spirit of brotherhood" (UDHR: 4). It is this premise that led the committee to declare, among many other rights that every human being has a right to free speech, a right to live in freedom and safety, and a right to freedom of religion of choice. I need to add more detail to Mignolo's (2009) argument that the Euro-American thought in the UDHR's resolutions can be traced right from the medieval charters like the 1215 Magna Carter or the Great Charter of Freedoms of King John of England. It is also rooted in the United States' Declaration of Independence and the Bill of Rights of 1787 and the 1789 French's Declaration of the Rights of Man, which, in fact, Roosevelt quotes in her 1948 speech to the United Nations. Most of these proclamations of universal bills of human rights concern (white) men only and not women or non-whites (except, to some extent, 
the French Declaration). Like France's Rights of Man, the UDHR is said to be universal, valid at all times in every place - for all people of all nations - an "international Magna Carter of all man everywhere” (Roosevelt, 1948: 3). In her 1958 speech, Eleanor Roosevelt rhetorically asks on where the human rights begin, and says that they begin in "small places, close to home - so close and so small that they cannot be seen on any maps of the world, yet they are the world of individual persons" (Roosevelt in Facing History and Ourselves 2010: 228). One may be tempted to ask after reading Foe, which home, which world, which individual? Indeed, I need to re-echo that on the declaration of the document, Roosevelt (1948: 1) mentioned that while the document was not perfect and cannot satisfy every delegate represented, "the whole delegation of the United States believes this is a good document." While this is not a review of the UDHR, I propose that the universalisation of human rights ignored the coloniality of other nations in the vice grip of super powers since its principles was to "lift men everywhere to a higher standard of life and to a greater enjoyment of freedom" (Roosevelt, 1948: 3). Ironically, while promoting the human rights of all people in all nations, some people were not seen as people since they had no voice and continued existing under colonialism. By 'all people' and 'in nations', those in the zones of non-being are excluded from the human family by the same document which purports to protect them. In a way, Susan illustrates this when she remarks of Friday, "he desires to be liberated, as I do too. Our desires are plain, his and mine. But how is Friday to recover his freedom, who has been a slave all his life? That is the true question" (Coetzee 1986: 148).

Indeed, the true question is, how and when do those in the zones of non-being become human? Under what conditions is it permissible to speak for others? This simultaneously is to ask, under what conditions is it permissible not to speak for others? However, to ask the second question is to assume already that others cannot speak for themselves. Indeed, to ask such questions is to depart from postcolonial and postmodernist analysis of the Coetzee' fiction. In a postmodernist analysis, critics like Attwell (1990) are worried about linking J.M. Coetzee's fiction to that of its intertexts. Some of Coetzee's texts that have enjoyed comparative reads include texts like Waiting for the Barbarians which is often compared to Becket's Waiting for Godot, to Cavafy's poem Waiting for the Barbarians and to Buzzati冈s novel The Tarter Steppe. Similarly, Poyner (2009) embarks on poststructuralist/ postmodernist ways of analyzing Coetzee's fiction. Poyner (2009), like Attwell (1990), juxtaposes Coetzee's characters with some of its key intertexts, for example Cruso with Crusoe of Daniel Dafoe's characters in the novel Robinson Crusoe (1719). Arguably, while my reading may fall in the trap of comparative study, it is only so in as far as showing the historicity of marginalization is concerned. I am preoccupied neither with the denial of 
the voice to the oppressed nor its importance, but I seek to question the silencing of the voices through their non-receptiveness. Similarly, because of this denial, how the oppressed conceptualize their shared socio-political world.

I argue that Coetzee's (1986) uses fictional techniques in problematising the question of voice and critiques the authority of the storyteller. In other words, to critique the authority of the story teller is to show how the oppressed like Friday, powerless as he is, has been conceptualised by Susan and Foe as the perpetrator of violence and a human eater. This way, like many conceptualisations of powerful organisations like United Nations Organisation (U.N.O) that still preserve veto powers to powerful nations and North Atlantic Treaty Organisation (NATO) and many others, Susan and Foe have formed an alliance of opinion against Friday. Ironically, Friday is known through their eyes because they are authorities speaking for him. Similarly, even if the UDHR is that of basic principle of human rights and freedoms and not statements of law, their enforcement today suggests that the document is an authoritative statute. By now, it has become clear that human rights, like the right to freedom of speech that must be enjoyed by everyone everywhere, remains an infinite ideal to strive toward, but an unachieved goal. This also means people and nations in the zones of non-being are not human since the colonised and the coloniser cannot be said to be enjoying the same freedoms ${ }^{1}$. In fact, today, like Friday, the zones of non-being depend on the zones of being in a neo-colonial world set-up. In Foe, the inequalities of individuals, of people and communities have been affected by the colonial wound (the very fact of the existence of the abyssal line even in crafting laws or principles that must be universal). Bannet (1997: 22) has noted, how, because of colonial effect, institutionalised organisations of social discourse decide certain utterances should fall outside of what is recognisable and legitimised as audible speech. The world is approaching a century since the birth of UDHR, yet the rights of (some) Man, especially those who cannot speak for themselves remain unaccomplished. While this paper seeks to investigate representation and the dilemma of the right to speech in Coetzee's (1986) Foe, it also challenges UDHR's assumption that human beings are born equal, born free and born all in the zones of being. The argument advanced here is that the hierarchisation of humanity into two zones is a form of silencing the not quite civilised, the not quite human, the women and servant figures in the colonial capitalist world system. In this way, and by juxtaposing Coetzee's novel with

1 Arguably, while the West is somehow or still responsible for the lack of rights in African, Asian and Latin American countries post-independence (for example some Western governments and corporations supporting or even installing military dictatorships in many countries), I am aware that in some independent countries today, it is the black elite rulers that suppress and withhold rights from citizens. 
the UDHR, this decolonial argument offers new insights in Coetzee's characterisation and thematicisation, and furthers the ongoing debates on Coetzee's literary writings.

\section{J. M. Coetzee and the crisis of representation}

With the basic outline of the flaws of equality at birth, of equal freedoms of speech based on the universalisation of rights, I argue that Coetzee's Foe (1986) challenges the view that those on the zones of non-being enjoy the same rights with those on the zones of being. Nonetheless, if all humans are born equal but do not remain equal after birth (or for the rest of their lives), then "losing their equality is a humiliating experience" (Mignolo 2009: 7). Indeed, if the equality is lost after birth (when, in fact, humans are equal at birth) it also suggests that those who are less equal than others lose their voice and those who are more equal than others assume the role of speaking for and about them. It has been the role of the humanist, authorised by the very same concept of being human (which is an invention of European Renaissance), to speak for man and for the human (Mignolo 2009: 9). It is the reference of civility or Roosevelt's (1948) promise to a higher standard of life that we decode in Foe that the whole concept of humanity is based on the modern subject, those who are able to record their history. It is, as Mignolo (2009: 10) avers, the reference to civility such that the humanitas and civitas presupposed the human to be educated and be able to record life (man being conceived as the body and mind). Cruso's inability to record his island sojourns is what sets him apart from the Empire; it is in fact, what distinguishes him from Dafoe's (1917) Crusoe. However, his ability to re-write or narrate his story orally and that which he thinks is Friday's story is again what ties him to the Empire. I wish to suggest that it is not Cruso's inability to write nor his ability to narrate orally his story and that of others but it is his privileged position, the fact of belonging to the zone of being that makes him have a listener even if he does not have a documented story like Crusoe. Indeed, it is not only the absence of language that creates disabled and un-able beings, but it is the disqualification of language or voice that disqualifies some people from humanity. Furthermore, Friday proves that he is not a simpleton since he challenges this view of being [not] spoken of, a view challenging that to be human is not based on the ability to speak or record. He disputes the imperial definition of being human. In other words, Friday's silence disapproves and a way of protest against any human inequalities; he protest against a society build on unequal principles. Friday's society prevents classification and ranking that justifies domination and exploitation. 
There has been no doubt that J. M. Coetzee's Foe (1986) is a pastiche of Daniel Dafoe's (1719) The Life and Strange Surprising Adventures of Robinson Crusoe, Of York, Mariner. Daniel Dafoe's story has been considered to be a "true" account and not fiction. In other words, Coetzee's re-writing of Dafoe's story (or the re-writing of history as fiction just like what Foe attempts to do with Susan Barton's story) problematises the inaccuracies and uni-linear idea of history that has presented the other as ontologically inferior. In other words, Coetzee (1986) questions what Alcoff (1991: 7) characterises as the "practice of privileged persons speaking for or on behalf of the less privileged persons [and that it] has actually resulted (in many cases) in increasing or reinforcing the oppression of the group spoken for." In Dafoe's story Friday has a tongue and is the aptest scholar who is taught how to speak - a phenomenon which, when simplistically read, leads to Friday's salvation just like Susan's rescue of Friday in Coetzee's Foe. Indeed, in his Nobel Prize acceptance speech, Coetzee (2004) metaphorically demonstrates the importance of a voice (or of telling one's story), and somehow highlights the dangers of suppression of voice by presenting Crusoe (Him) reading the stories of his man whom he questions: "what species of man" send such reports? (Coetzee 2004: 550). Cornwell (2008) reads the speech as a highlight of the relationship Crusoe or Coetzee has with his characters as they write their stories, and that it points out the gulf that exist between author and character. However, like his "man" who sends "Him" reports of clubbings, beheading and plagues, the speaking Friday in Dafoe's Robison Crusoe (and an epigraph that Coetzee quotes in the beginning of his speech), reveals that Friday, like Crusoe's parrot, only speaks what he has been taught in order to be useful to him.

Unlike Coetzee's Cruso as already established, Dafoe's Crusoe keeps a diary and documents his experiences, and in $\mathrm{He}$ and his man, Crusoe (who now finds writing very difficult) is seen enjoying reading the reports sent by his man. In re-writing Dafoe's Crusoe, Coetzee reminds readers that the invention of people, just as Columbus and Cruso contrastingly do, does not need to be necessarily written down. Columbus' 1492 journal as Peter Hulme summarises it in Ashcroft et al (2007: 365 - 6) captures his discovery of cannibals in Africa and people who had one eye in their foreheads. It is the "singular" or "lenient master" Cruso, as Susan describes him, who (like Columbus regardless of written records) exposes the exponential location of the speaker as an insufficient position to speak for others (Coetzee 1970: 11 and 23). In Coetzee's story, three castaways, Friday, Cruso and Susan find themselves marooned on an island. Cruso tells Susan that he saved Friday from his cannibal tribe and that Friday cannot talk because his tongue was ripped out (even though there is no evidence in the novel except for Cruso's inconsistent accounts). 
Nevertheless, Friday's absent tongue is his first dehumanisation. In other words, Cruso is not only speaking for Friday or inventing history just like Foe does with Susan's story (and perhaps, just like Coetzee does with Dafoe's story) but assumes a new place of discovering the island and even new semi-people like Friday and becomes the master of both. This also means that the island and Friday did not exist before Cruso's arrival. In this way, Coetzee (1986) portrays colonial forms of definitions of humanity, of domination and exclusion.

In fictionalising Dafoe's "true" account, Coetzee problematises the question of humanity by questioning both the right to equality at birth ${ }^{2}$ and the right to express oneself freely - which according to the UDHR are the universal tenets that ought to describe human beings. That is, if one is denied an opportunity to be human as we read of Friday and later Susan and Foe, then one is denied an opportunity to live. While the story before us is Susan's letters to Foe, meant to be properly retold by a professional story teller, the story as it is told in Susan's voice is not a story proper, it is a raw material of the story that does not fit the expectations of the publishers, or the established capitalist expectation of storytelling. In fact, Coetzee's title of the novel should, according to Susan, preferably read, "The Female Castaway. Being a True Account of a Year Spent on a Desert Island. With Many Strange Circumstances Never Hitherto Related" (Coetzee 1986: 67). Like Friday who does not have a voice, Susan as a gendered woman has no voice, since her story can only be a story with the help of Foe. This also means that despite Susan having a voice, she does not have a voice because she cannot be heard and is considered a second-class citizen in her home country. Indeed, if Susan is a second-class citizen, it is worse for the third- or even fourth-class citizens of the world like Friday. Unquestionably, at stake is Susan's being or her human rights because at one time she had to disguise herself like a man by pinning her hair up and wearing a coat at all times in order to pass between soldiers at Windsor Road - a clear indication that, regardless of the declaration of human rights, modern/colonial societies do not uphold that woman and man remain equal after birth ${ }^{3}$ (rights de facto). As Mignolo (2009: 7) avers, "the problem is that if men (and women) are born equal, they do not remain equal the rest of their lives." Indeed, Foe insists that Susan's story should be told in a familiar way (a way which includes fictitious tales): "the loss, then quest, then recovery: beginning, then middle, and the end" (Coetzee, 1986: 117). In his insistence to

2 I need to mention that every human is equal in rights de jure, even though they de facto may not enjoy these rights because of the circumstances in which they live.

3 It appears the historical period during which Foe is set precedes even the American and French declarations. However, since Coetzee writes Foe in late 1980s, he may be sensitive to these historical contexts. 
write a perfect story, Foe attempts to re-write Susan's story, and ultimately Friday's story. Susan tells Foe: "I told you of my conviction that, if the story seems stupid, that is only because it so doggedly holds its silence. The shadow whose lack you feel is there: it is the loss of Friday's tongue" (Coetzee, 1986: 117). The fact that Foe is a writer on the run from his creditors suggests how the world revolves around the coloniality of power such that few people who control the capitalistic markets influence the societies' ideologies, such that, even those in the zones of being bow to the power of the few. In the level of representation, one does not fail to read the censoring of the voice in Foe which may be due to the zone one occupies. Even in the zone of being, there appears to be social stratification in such a way that power only speaks to power.

However, even after hearing Friday's story from Cruso, and since her own story can be completed by Friday's, Susan proclaims that her story is not complete because she does not trust Cruso's stories about Friday. In other words, it is Friday's story that completes Susan's not the other way round - a clear indication that even Friday (because he cannot be excluded in Susan's story) has a right to exist. The consequences of silencing Friday, like the silencing of any other slave, is an effort to have monolithic stories, and to have those in the zones of non-being as complementary to the stories of all in the zones of being. All things equal, even if Friday had a voice like Dafoe's (1917), he would (like today's Third World countries) have continued to be a spectacle of marvel. As a citizen of the Third World, Friday's voice was not going to make him human since, even the idea of hierarchising humanity into First, Second, Third and even Fourth World has everything to do with the rights and the voice in order for the First World to benefit economically. Indeed, who is human in the human rights is a matter of concern. Braidotti (2013:24) posits that "the idea of being human was born in Europe and was shaped through capitalist mouldings to be he [...], he is white, European, handsome and able-bodied.” Even in her proclamations that all humans are "substantial beings with substantial history in the world," Susan seems to be having a particular form of a human in her mind which does not include the substantiality of characters like Friday (Coetzee 1986: 131). This questions the very principles of the idea that all human beings are born equal at birth. Even if Susan proclaims that her story is not complete without that of Friday, Susan's account, incomplete as it is, is a conscious attempt to speak for and about Friday. It is, indeed, not an ignorant attempt given the fact that Friday, literarily, has no voice. Spivak (1989: 298) has questioned if the subalterns can speak since they have no voice, and she challenges those with a voice not to ignore the voiceless since this will be "to continue the imperialistic project." Even if this is the case, it is not a given that those who cannot speak for themselves need advocacy - even if the onus 
is on the speaking subject to represent as accurately as possible the stories of the voiceless.

Alcoff (1991: 7) views the practice of speaking for others as reinforcing the oppression of the person or group spoken for. It is an accusation that equally applies to Cruso, to Susan, to Foe and to Coetzee as the author. The charge is not only that of attempting to speak for Friday, the additional charge is that of making no attempt to speak for and about Friday. That is, both the attempt of [not] speaking for and about Friday constitute an occlusion, an admission that he is not human. However, although Coetzee has been characterised as an elusive writer, the one who avoids taking a stand in a country like South Africa that suffers from so many social and political ills, I want to argue that such a charge against him is irresponsible, and if all human beings have a right to a fair trial, then Coetzee's writing dilemma has to be explored fully before any judgment is passed. Coetzee (1986) seems to challenge any allegations that he is an elusive writer. Parry (1991: 199) turns to Coetzee as the silencing author and asks, “does not Coetzee's own principled refusal to exercise the power of the dominant culture by speaking for others paradoxically perform the discursive process of silencing?" If he is elusive, there seem to be no way Coetzee can demarcate the boundary between himself and his fictive figures. Alcoff (1991: 20) asserts that "a complete retreat from speech is of course not neutral since it allows the continued dominance of current discourses and acts by omission to reinforce their dominance." Indeed, if elusiveness is a charge against Coetzee, then it does not obtain how an unnamed narrator has been brought into the narrative role in the last chapter, and how a conscious Susan has been made to write, in a letter form, her accounts to Foe.

Indeed, when Susan speaks of her story, she is not only speaking of herself, since the possible construction of herself (her way to exist in the world) is offering that to Foe, Cruso and Friday - whether she intends it or not. That is to say, Susan's voice or her ability to speak about herself and her story impacts on the stories of others - that of Cruso and Friday and even that of Foe. Indeed, when Susan speaks of herself, she is "constructing a possible self, a way to be in the world, and [she is] offering that to others, whether [she] intends it or not, as one possible way to be" (Alcoff 1999: 21). Therefore, there appears to be no way one can be immune to criticism or errors of representing one's speech because errors are unavoidable and they make valuable contributions (Alcoff 1991: 21). The questions that seek to be explored is on what basis can the author or other characters decide to and not to speak for and about others? If one does not speak for and about the less privileged can that be a form of violence or abandonment? As is the case with Friday, how can one keep silent or make his silence speak, and should all instances of speaking for and about those who cannot speak for themselves be condemned in all cases? 


\section{To speak or not to speak, that is the question}

While a close reading of Foe raises questions on [not] speaking for and about others, it does little in presenting any possible solutions. Consider, for example, the way how Susan represents Friday when she first saw him:

A dark shadow fell upon me, not of a cloud but of a man with dazzling halo about him. [... The man squatted down beside me. He was black: A Negro with a head of fuzzy wool $[\ldots]$ flat nose, small dull eyes, the broad nose, the thick lips, the skin not black but a dark grey, dry as if coated with dust. (Coetzee 1986: 1-2).

After she was cast adrift with the dead captain's body by the crew of the ship she was travelling in, Susan is rescued to safety by Friday. However, as soon as Susan sees a spearcarrying Friday, she is struck by his physical features and concludes that "[she] has come to an island of cannibals" (Coetzee 1986: 2). To Susan, Friday's physical appearance authenticates the existence of a different world closer to bestiality, where semi-humans are perceived as human eaters - it is a view that Susan has of Friday every time she sees him eating; she imagines if human flesh passed his lips. She writes, "Truly cannibals are terrible, but most terrible of all is to think of cannibal children, their eyes closing in pleasure as they chew the tasty fat of their neighbour" (Coetzee 1986: 94). What Susan seems to express is the discomfort of imagining the anthropos ${ }^{4}$. Susan often wonders when she sees Friday dancing, that "his thoughts are far away, not on the island, $[\ldots]$ but on the time before, when he was a savage among savages," and expands that Friday will soon revert to his old Friday of the cannibal forest (Coetzee 1986: 95). The awareness of racial differences, and the fictive stories made up in the zones of being, as we witness in these attempts to construct Friday, are the ways of creating a center where humans exist, and the periphery where the nonhuman, the dis-human and the human-to-be exist. It is not only these constructions and lasting images of Friday that are left with the reader, but Cruso's inconsistent tales as well, and the casual dismissal of Friday's existence by Foe in England. In explaining to Susan of Friday's voicelessness or tonguelessness, Cruso says that "the slavers cut out his tongue and sold him into slavery" (Coetzee 1986: 23). The sketch given of Friday, his production

4 Nishitani Osamu's anthropological categories of humanitas and anthropos delinks from Euro-American modern terminology of the self and other respectively. Thus, humanitas and anthropos as terms refer to 'self' at the center and anthropos to the 'other' at the periphery and, as constructed terms, are utilised to legitimatise one race and dehumanise the other. 
by the center as physical, rationally and racially different, is an attempt to create disabled beings whose freedom and rights are and cannot be documented. In this way, "being human means to be rational - rationality limited to the definition of Western philososphers and Enlightenment theorist" (Mignolo 2009: 14). That is, the fact that Friday has been reproduced as disabled and irrational, and at the mercy of his masters means that as a "slave and a child, [he is not human and rational enough to look after himself] it was [their] duty to care for him in all things, and not abandon him to a solitude worse than death" (Coetzee, 1986: 39).

The consequences of caring for Friday in all things means deciding if Friday wanted to travel to England and to live as a slave in the non-human zone, the masters have the right to speak for him. To this end, it is still not clear if Susan, Cruso, Foe and even Coetzee have the ethical right to speak or not to speak for Friday (this situation is complicated by the fact that Friday is Coetzee's fictional creation). Guided by Spivak (1989) the question is partly answered in her essay Can the Subaltern Speak? In her highly acclaimed paper, Spivak (ibid) criticises Michael Foucault and Gilles Deleuze for "rejecting speaking for others on the grounds that it assumes the oppressed can transparently represent their own true interest” (Spivak in Alcoff 1991: 22). Indeed, Spivak (1989) demonstrates how Foucault and Deleuze occupy a defensive position and how this retreat illustrates how power can be concealed. The question that has not been answered so far is who is supposed to hear, and whoever is supposed to hear is she/he or are they prepared to hear the language and voice of the anthropos of this world? Clearly, those who occupy the zones of being, who are supposed to speak for and about others are the same who are supposed to listen. To return to Foe, are those in the zones of being like Foe, prepared to listen to the likes of Susan who are silenced by gender or even to the colonial silences of Friday? Spivak (1989) has demonstrated that speaking (and I must add, listening) is subject of knowledge which carries in it underlying ideologies. In looking at the ideologies underlying Foucault and Deleuze's conversations, Spivak (1989: 66), challenges the assumption that "intellectuals must attempt to disclose and know the discourse of society's other." As already noted, this on its own is a questionable postcolonial suggestion where the anthropos is a subject of study. In trying to understand the discourse of the anthropos in order to speak for and about the anthropos the speaking subject cannot escape the risk of being accused of a privileged position or committing errors as already seen in the UDHR and the speaking subjects in Foe. Arguably, understanding the discourse of the anthropos somehow avoids monolithic stories - stories similar to Hegel's phenomenology of the Spirit where Europe is the centre of modernity. It is worthwhile noting that Dussel (1993) and Mignolo (2000) 
have critiqued Enlightenment scholars like Descartes, Kant and Hegel for locating Europe as the centre of modernity. Today, Europe has been joined by America, Russia and China with their own monopolies. Like Spivak (1989), Dussel (1993) and Mignolo (2000) charge that speaking as the object of knowledge promotes monolithic stories especially about the Third World subject. Indeed, this is the case of Cruso's made up stories and Foe's instances of viewing Friday as a descendent of the cannibals. Even if Susan proclaims of her substantiality, and that everyone is substantial, the reader is still not convinced that, Susan as a speaking subject, believes that Friday is substantial as she and Foe.

However, Alcoff (1991) has explored expansively the problem of [not] speaking for and about others. Alcoff (1991: 6) has questioned if "it is possible to adequately and justifiably speak for others?" As a question central to this paper, it is a question I keep returning to in my reading of Foe. The problem of speaking for others is that it makes those spoken of or about discursive subjects. Despite the degree of verisimilitude of the represented speech since representing someone's speech affects the meaning and truth of what was said, speaking for others suggests that the speaker occupies a privileged location (epistemically or otherwise) which Alcoff (1991: 7) characterises as "discursively dangerous." Susan protests that she "will not have any lies told [... that she] would rather be the author of [her] story than have lies told about [her]" (Coetzee 1986: 40). As Susan often insists on the truthfulness of her story, does speaking for others represent the truth? Part of the danger of speaking for others is the denial of human equality and freedom of speech (their own speech). A popular argument that may be advanced here are the benefits of political and democratically representations of communities, where elected people assume the right to speak for others. A number of questions hence can be asked if the speaker speaks for the group of which he or she belongs. However, it is a complex argument as Coetzee portrays in Foe, where even Cruso or Foe cannot speak for Susan even if she belongs in the zone of being.

To return to the question of [not] speaking for and about others, if the problem is not only the idea of speaking for and about others, but also the idea of refusing to speak for and about others, as Spivak (1989) challenges, then, as Foe demonstrates, the question of humanity or human rights is in a dilemma. This is to say, if [not] speaking for and about others is an affirmation that the anthropos is not human, then in either case the anthropos does not exist, the anthropos appears and disappears at the same time. In this way, the speaking of and about or the refusal by Burton or Foe to speak for Friday, or the manipulation of Friday's story by Cruso and later Foe is the dilemma that Coetzee confronts in the last chapter of the novel. In the last section of the novel, Coetzee constructs 
an impartial narrator who, despite viewing Susan and Foe in deep slumber resembling that of death, fails to get into Friday's mouth even though the narrator hears the loud noise of silences emitted from his mouth, and notices that at the back of Friday's neck there "is a scar like a necklace, left by a rope or chain" (Coetzee 1986: 155). Friday's untold story of slavery, or his corrupted story in the hands of Susan, of Cruso, of Foe and even Coetzee does [not] speak for those less privileged, it may be decoded as forms of rewriting history, and of neglect and abandonment. Bennet (1997: 22) says that "a self-righteous refusal to speak for others $[\ldots]$ threatens to reproduce the denial of audible utterances to subaltern subjects." That is, if one chooses to be silent the justifiable gesture as Coetzee shows, is to make this silence speak. Friday's silence speaks because Cruso and Susan's stories are not complete without that of Friday, and as Susan observes, it is a silence that "rises up the stairways like smoke, like welling of black smoke" (Coetzee 1986: 118). Indeed, Cruso's decision to speak for himself (and in many instances inventing Friday's stories) is irresponsible and problematic since he re-creates himself as a humanist who saves Friday from cannibals and starvation (Coetzee 1971: 12). That is, those who choose to speak or not to speak (or those who choose what to say about those who cannot speak) are already positioned at the centre (in the zones of being) where they enjoy privileges of choices. Alcoff (1991: 24- 5) notes that "making the decision for oneself whether to retreat is an extension or application of privilege, not an abdication of it." Indeed, as Alcoff (1991: 12) has noted, the speaker who speaks or chooses to be silent can no longer be neutral because "what is said turns out to change according to who is speaking and who is listening." In this way, I add, what is not said turns out to be influenced by who is speaking and who is listening. However, the risk of speaking for others is what Susan attempts, and Foe shows that it is a worthy risk if the speaker and listener are conscious about those who cannot speak for themselves. Spivak (1989) demonstrates that trying to understand the anthropos' discourse in the practice of speaking for and about is a better initiative than to be silent. However, that does not prevent a case being made of Cruso and Foe's invention of Friday and Susan's stories to suit them or to suit the markets. Like UDHR's concept of human and human rights, it is a charge of power speaking and listening to itself: it is a case of power speaking to power.

\section{Can the Third World Subject Speak?}

The dilemmic praxis of the non-speech of the non-human that Spivak (1989) pondered on in her essay when she asks if the subalterns can speak is still relevant today. Spivak's (1989) question inquires whether the citizens of the Third World can speak. Do the citizens of 
the so called Third and Fourth World need to be spoken of or about, or they can speak for themselves? It is a question that asks if those on privileged positions can morally and ethically afford to be silent on the voiceless others. Indeed, it has been realised that Third World citizens have long been speaking for themselves, but the question is whether they are heard, do they have a voice or are they the Fridays of this world? While Alcoff (1991) demonstrates that "the practice of speaking for others remains the best possibility in some existing situations," speaking for others is a practice that does not only speak of advocacy, but a tell-tale of the knowing agents of knowledge speaking of objects. The solution is not for Friday to speak for himself, nor for him to make a speech whatsoever since that will be ineffective except to complete Susan's story. Susan's consciousness has to be applauded since she appears to speak in the spirit of honesty by offering her biographical account and re-tells Cruso's tale as it is. Susan's critics, where the illustration of her errors and ignorance, for example, of re-locating Friday to Britain, her attempts to give Friday the Eurocentric voice of being able to read, write and speak so that he may be semi-human, and of subjecting Friday to Eurocentric excesses of food that has made him unhealthy and obese. Indeed, the perpetrators and violators of human rights like Susan and Cruso legitimise themselves as saviours. Furthermore, it is in England that Friday is further treated as a spectacle of cannibal wonder; evidenced by three boys who are found "at the cellar door peering in on Friday" at their lodgings in Clock Lane (Coetzee 1986: 55). These perceptions of Friday have to be critiqued since readers have access to Friday's personality and features through what Susan says from her privileged or semi-privileged position. Furthermore, such recognition of non-similarities justifies discrimination, domination and segregation.

To avoid the dilemma of speaking for and about others, Alcoff (1991: 23) suggests that "we should strive to create wherever possible the conditions for dialogue and the practice of speaking with and to rather than speaking for others." As we witness, in occluding the tongueless, voiceless, rootless and kinless Friday, Coetzee illustrates the impossibility of the privileged to speak with others. In other words, Susan and Foe do not see the possible spaces to create such dialogues. The impossibility is precisely that under the Eurocentric modernity, everything has to be understood from such privileged perspectives. Coetzee portrays the self-conscious appropriation of the other against power relations such that Cruso's act of speaking for Friday and all his people (rather than speaking with him) is an act of disempowerment. Indeed, Susan Barton's hesitancy and limitations she faces in writing her story, or her act of writing her story through the letters to Foe illustrates her consciousness that there is no equality at birth. It is, indeed, her consciousness is the centre of attention. Of their time on the island, Susan notices that "shipwreck is a great 
leveller, and so is destitution, but we are not level enough yet” (Coetzee 1986: 70). Indeed, Cruso remains an authority over Friday, who upon Susan's arrival, makes Friday double his slave duties to serve his two masters. However, in her act of documenting her tale, Susan demonstrates that the authority to speak and to be heard is, indeed, privileged.

However, Coetzee appears to be creating a space for dialogue where Susan can learn from Friday through the blowing of the flute. Susan notices that "[Friday's] tune, of which he seemed not to tire, grew so to annoy me that one day I marched over and dashed the flute from his hands [...]" (Coetzee 1986: 28). Elsewhere, Susan wonders how Friday keeps on returning to his tune and it occurs to her that if there is any language that Friday speaks it is the language of music (Coetzee 1986: 96). It is in her preparedness to learn Friday's tune that Susan comes closer to understanding the discourse of the other. Susan says, "So I closed the door and practiced the blowing and the fingering as I had seen people do, till I could play Friday's little tune tolerable well, and one or two others, to my ear more melodious" (ibid). From then on Susan and Friday harmoniously play the tune and Friday dances too. However, it is when Susan demands Friday's attention by varying his tune that Friday does not follow her. She remarks that it dawned on her that "it might not be mere dullness that kept him shut up in himself, nor the accident of the loss of his tongue, nor even an incapacity to distinguish speech from babbling, but a disdain for intercourse with me" (Coetzee 1986: 98). Friday's refusal to dance to Susan's tune is indeed a refusal to be human on her terms, just like his refusal to speak and learn how to write. Indeed, Susan questions her motives of educating Friday, "I tell myself I talk to Friday to educate him out of darkness and silence. But is that the truth? [...] I use words only as the shortest way to subject him to my will” (Coetzee 1986: 60). Indeed, as Susan questions, if Friday “was not a slave, was he nevertheless not the helpless captive of my desire to have our story told?" (Coetzee 1986: 150). With this in mind, I wish to suggest that Friday rebels against the violation of his own views of dignity in order to exist. Yet again, Susan's advocacy for Friday to dance to her tune, after having abandoned Friday's old tune illustrates that it is not advantageous to speak with and to the other in today's capitalistic world.

\section{Conclusion}

In summation, what follows my reading of Foe has partly suggested that the practice of speaking for and about others, problematic and oppressive in nature, ought to be practised with caution, and that there is no escape from committing errors and avoiding criticism. Furthermore, I have problematised the practice of speaking for oneself as a less helpful 
position which somehow Susan consciously does. The power of those who speak, like Foe demonstrates and assumes that (like seen in Hegel's freedom of the Spirit) is universal. Indeed, as Foe has attempted of Susan's story, UDHR falls into dangers of expanding into authority and privilege by not speaking for or misrepresenting others or falling into the imperialist speaking ritual. Either way, as we have noted, attempts to speak for oneself or for the other cuts off that person's willingness to engage in constructive act of developing meaning (Trebilcot in Alcoff 1991: 19). While everyone's account needs to be encouraged as Susan seems to do with Friday, the tools Friday is required to use are that of the master - tools one can view as boding violence. Indeed, while his right to speech is encouraged, Friday's refusal to speak on the masters' terms is an affirmation that speaking is not necessarily the articulation of one's voice, there are other forms that constitute the right to speech. In fact, by either refusing giving Friday a voice, or even giving Friday a voice in a brief dreamlike last chapter, Coetzee demonstrates that speaking for oneself, for and about others, or to and with others cannot be abandoned. Perhaps like Lewis MacLeod (2006: 7) asks of Coetzee's fiction, if his characters and readers do not have a voice "do we of necessity become puppets in a story?" I will like to extend this question: if we do not have a voice and are denied the right to free speech, do we of necessity become puppets in the world?

\section{References}

Alcoff, L. (1991). The Proble of Speaking for Others. Culrural Critique, 20, 5 - 32.

Ashcroft, B., Gareth, G., \& Tiffin, H. (2007). Post-Colonial Studies: Key Concpets (2nd ed.). New York: Routledge .

Attridge, D. (2004). J.M. Coetzee and the Ethics of Reading. Chicago: University of Chicago Press.

Atwell, D. (1990). The problem of history in the fiction of J.M. Coetzee. Poetics Today, 4(3), 579-616.

Barnett, C. ( 1997). "Sing Along with the Common People”: Politics, Postcolonialism, and

Other Figures. Environment and Planning D: Society and Space, 15(2), 137 - 154.

Boyd, M. (1983 ). The Reflexive Novel: Fiction as Critique. Wisburg: Bucknell UP.

Braidotti, R. ( 2013). The Posthuman. London: Polity.

Chapman, M. (1988). The writing of politics and the politics of writing. On reading Dovey on reading Lacan on reading Coetzee on reading... (?). Journal of Literary Studies, 4(3), 327-341.

Coetzee, J. M. (1977). In the Heart of a Country. London: Vintage. 
Coetzee, J. M. (1986). Foe. London: Martin Secker \& Warburg Ltd.

Dafoe, D. (1719). The Life and Strange Surpising Adventures of Robinson Crusoe, Of York, Mariner. London: William Taylor.

Dovey, T. (1988). The Novels of J.M. Coetzee: Lacanian Allegories. Craighall: AD. Donker (PTY) LTD.

Dussel, E. (1993). Eurocentricism and Modernity (Introduction to Frankfurt Lectures). Boundary, 20(3), 65 - 76.

Facing History and ourselves . (2010). Fundamental Freedoms: Eleanor Roosevelt and te Uiversal Declaration of uman Rights. Brookline: Facing History and Ourselves National Foundation Inc.

Fanon, F. ( 2004). The Wretched of the Earth. . New York: Groove Press.

Foxcroft, N. ( 2013). The Power of Non-Verbal Communication in J. M. Coetzee's Foe. The European Conference on Arts \& Humanities 2013. UK: University of Brighton.

Gordon, R. L. ( 2007 ). Through the Hellish Zone of Nonbeing: Thinking Through Fanon, Disaster, and the Dammed of the Earth. Journal of the Sociology of Self-knowledge. Jurnal of the Sociology of Self-Knowledge , 5(3), 1 - 30.

Lugones, M. (2010). Towards a Decolonial Feminism. Hypatia, 25(4), 742 - 759.

MacLeod, L. (2006). “Do We of Necessity Become Puppets in a Story?” Or Narrating the World: On Speech, Silence, and Discourse in J. M. Coetzee's “Foe”. Modern Fiction Studies, 52(1), 1-18. Retrieved from https://www.jstor.org/stable/26286920

Maldonado-Torres, N. (2007). On the Coloniality of Being. Cultural Studies. , 21(2), 240 -270 .

Maldonado-Torres, N. (2017). On the Coloniality of Human Rights. Revista Critica de Ciencias Sociais, 114, 117 - 136.

Mbembe, A. ( 2017). Critique of Black Reason (Vols. Mbembe, A. 2017. Critique of Black Reason. Translated by Laurent Dubois. Durham: Duke University Press.). Durham: Duke University Press.

Mignolo, W. D. (2000). Local Histories/Global Designs: Coloniality, Subaltern Knowledges, and Border Thinking. Princeton: Princeton University Press.

Mignolo, W. D. (2009). Who Speaks for the Human in Human Rights? HIOL - Hispanic Issues on Online, 5(1), 7 - 24.

Mignolo, W. D. (2011). Epistemic Disobedience and the Decolonial Option: A Manifesto. Transmodernity, 44 - 66. 
Mullins, C. C. (2009). Silence as Insubordination: Friday and Michael K's Wordless Weapon, A Post-colonial Approach to J. M. Coetzee's Foe and Life and Times of Michael K. MA Dissertation : Marshall University.

Nations United. (2015). Universal Declaration of Human Rights. New York.

Parry, B. ( 1991). J.M. Coetzee: White Writing. . Research in African Literature, 22, 196 199.

Poyner, J. (Ed.). (2006). J.M. Coetzee and the Idea of the Public Intellectual. Athens: Ohio University Press.

Poyner, J. (2009). J.M. Coetzee and the Paradox of Postcolonial Authorship. Farnham: Ashgate Publishing Company.

Roosevelt, E. (1948, December 9). On the Adoption of the Declaration of Human Rights . Address to the United Nation's General Assembly, pp. 1 - 4.

Schallenberg, M. (2011). Articulating Substance: On Silence and Namelessness in J. M. Coetzee's Foe and Life and Times of Michael K. MA Dissertation .

Smet, D. S. (2009). J. M. Coetzee's Disgrace and Foe: An Analysis of Postmodern and Political Representation. MA Dissertation: University of Gent.

Spivak, G. C. (1988). Can the Subaltern Speak? . In C. Nelson, \& L. Grossbery (Eds.), Maxism and Interpratation of Culture (pp. 271 - 313 ). Basingstoke: Macmillan Education. 